\title{
Aktivitas Fisik dan Body Mass Index Pada Anak Usia Dini: Pengukuran MET's dengan Accelerometer ActivPAL
}

\author{
Rahmawati Ramdani ${ }^{1}$, ${ }^{*}$ Jajat (co-Author) ${ }^{1,2}$, Nana Sutisna ${ }^{1}$, Adang Sudrazat ${ }^{3}$, Risma ${ }^{1}$ \\ ${ }^{1}$ Program Studi Pendidikan Jasmani, Universitas Galuh Ciamis \\ ${ }^{2}$ Program Studi Ilmu Keolahragaan, Universitas Pendidikan Indonesia \\ ${ }^{3}$ PGSD Pendidikan Jasmani, Universitas Pendidikan Indonesia \\ e-mail: rahmawatiramdani14@gmail.com \\ diusulkan Juni 2019; diterima Juli 2019; dipublikasikan Oktober 2019
}

\begin{abstract}
ABSTRAK
Level aktivitas fisik dan body mass index (BMI) anak usia dini berhubungan erat dengan berbagai penyakit dan resiko kesehatan. Penelitian ini bertujuan mengkaji hubungan pengeluaran energi (MET's) aktivitas fisik yang diukur dengan accelerometer ActivPAL dengan BMI pada anak usia dini. Sampel berjumlah 65 orang anak usia dini berusia 4 tahun pada PAUD/Kober yang ada di Jawa Barat. Instrumen yang digunakan untuk mengukur aktivitas fisik adalah accelerometer ActiPAL yang dipasang selama 5 hari selama 24 jam pada partisipan. Hasil penelitian menunjukkan tidak ada hubungan yang signifikan antara pengeluaran energi aktivitas fisik (MET's) dengan BMI pada anak usia dini $(p>$.05) Perlu ada kajian lebih mendalam lagi terkait dengan hasil penelitian ini.
\end{abstract}

Kata kunci: BMI, aktivitas fisik, MET's, anak usia dini, accelerometer, ActivPAL

\section{PENDAHULUAN}

Overweight dan obesitas berkaitan erat dengan resiko berbagai penyakit seperti diabetes, tekanan darah tinggi, kolesterol, asthma, dan arthritis serta rendahnya kesehatan (Mokdad et al., 2015). Sementara itu berat badan rendah juga dikaitkan dengan rendahnya kualitas hidup yang berhubungan dengan kesehatan (Esselink et al., 2006; Katsura, Yamada, \& Kida, 2005). Rendahnya Body Mass Index (BMI) juga berkaitan erat dengan peningkatan mortalitas penyakit paru obstruktif kronik (Cao et al., 2012; Chong et al., 2004) Obesitas pada orang dewasa dikaitkan juga dengan peningkatan risiko sejumlah penyakit termasuk diabetes tipe 2 (Ford, 1999).

Salah satu faktor yang berkaitan dengan overweight dan obesitas adalah aktivitas fisik. Kurangnya aktivitas fisik diyakini menjadi faktor risiko yang dapat menimbulkan penyakit kardisovaskular dan berbagai penyakit kronis lainnya penyakit, termasuk kanker payudara, obesitas, hipertensi, penyakit tulang dan sendi (osteoporosis dan osteoartritis), dan depresi (Chodzko-Zajko, Wojtek J.,Proctor, 2009; Noûs, Division, \& Mar, 2018; Taylor, Rod S. Brown, 2004).

Inaktivitas fisik diakui sebagai faktor yang mempengaruhi risiko penyakit kardiovaskular 
(Fletcher, G. F.,Blair, S. N.,Blumenthal, J., Caspersen et al., 1992). Inaktivitas fisik juga merupakan kontributor utama epidemi obesitas (Gray et al., 2018).

Di Indonesia, penelitian mengenai hubungan aktivitas fisik dengan BMI telah banyak diterbitkan. Namun dalam pengukuran variabel aktivitas fisik aktivitas fisik sering dinilai dengan pengukuran laporan diri (Arnardottir et al., 2013). Laporan diri dapat membantu tetapi cenderung melebihlebihkan aktivitas fisik dari yang sebenarnya dan merendahkan atau mengurangi jumlah waktu sedentari (Chinapaw, Slootmaker, Schuit, Van Zuidam, \& Van Mechelen, 2009; Tudor-Locke \& Myers, 2001).

Kategori intensitas aktivitas fisik yang sudah dilakukan akan sulit untuk diingat (Baranowski, 2013). Apalagi dalam hal ini apabila sampel dalam penelitian merupakan anak-anak. Oleh karena itu perlu adanya kajian lebih teliti mengenai kaitan aktivitas fisik dengan BMI pada anak usia dini. Aktivitas fisik dalam hal ini diukur secara objektif dengan menggunakan accelerometer ActivPAL. Pengukuran secara akurat terhadap pola aktivitas fisik, perilaku sedentari dan waktu tidur dengan menggunakan monitor aktivitas fisik yang objektif (pedometer dan akselerometer), telah terbukti layak digunakan untuk mengukur pola aktivitas (Shephard, 2003). Adapun tujuan penelitian ini adalah mengkaji hubungan aktivitas fisik terutama energi yang dikeluarkan (METs) dengan Body Mass Index pada anak usia dini.

\section{METODE}

Partisipan dan Prosedur Pengambilan Sampel

Partisipan dalam penelitian ini adalah 65 orang siswa Pendidikan Anak Usia Dini (PAUD)/Kelompok bermain (Kober) yang berusia 4 tahun, orang tua siswa dan pendidik/guru.

Orang tua siswa terlebih dahulu diminta kesediaannya untuk berpartisipasi dalam penelitian dengan mengisi consent form. Orang tua yang setuju melibatkan anaknya untuk ambil bagian dalam penelitian selanjutnya dijadikan sampel terpilih. Penelitian melibatkan 9 PAUD/Kober di Kab. Ciamis.

\section{Pengukuran Aktivitas Fisik dan BMI Anak Usia Dini}

Instrument yang digunakan untuk mengukur aktivitas fisik yaitu ActivPAL. ActivPAL merupakan accelerometer yang dikeluarkan oleh PAL Technologies Ltd, Glasgow, UK dan telah banyak digunakan untuk mengukur aktivitas fisik. ActivPAL mengidentifikasi perubahan postur tubuh dari duduk dan tidur ke berdiri atau berjalan, merekam jumlah langkah dan irama jalan serta mengestimasi pengeluaran enegi dalam satuan METs. 

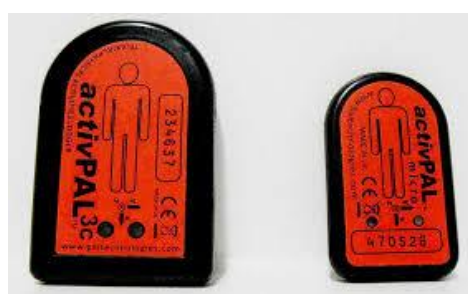

Gambar 1. ActivPAL

ActivPAL dipasang selama 5 hari pada paha bagian kanan anak. Plester tegaderm digunakan untuk menempelkan ActivPAL pada paha anak, sesuai dengan rekomendasi medis sehingga aman untuk digunakan.

Rumus BMI metrik digunakan untuk mengukur lemak tubuh. Tinggi dan berat diukur dengan menggunakan stadiometer (tinggi) dan skala elektronik (berat) sesuai dengan protokol standar.

BMI $=$ berat $(\mathrm{kg}) /[$ tinggi $(\mathrm{m})] 2$.

Partisipasn diukur tinggi badannya dan berat badannya dengan tanpa menggunakan sepatu dan berdiri di permukaan lantai yang rata. Pengukuran dilakukan dalam dua kali: jika terdapat selisih berbeda $0,5 \mathrm{~cm}$ atau lebih, atau $0,2 \mathrm{~kg}$ atau lebih, maka dilakukan pengukuran ketiga. Rata-rata dari dua pengukuran terdekat lalu analisis.

\section{Analisis Statistika}

Pengolahan data menggunakan program SPSS Serie 24. Pengujian dengan menggunakan analisis descriptive dan uji korelasi dan regresi.

\section{HASIL DAN PEMBAHASAN}

Hasil

Rata-rata pengeluaran energi aktivitas fisik anak usia dini adalah 34,34 METs dengan standar deviasi 1,22. Skor minimum 31,43 METs dan skor maksimum 37,97 METs. Sementara untuk BMI diketahui rata-ratanya adalah 14,72 dengan standar deviasi 1,03. Skor minimum adalah 12,45 dan skor maksimum 17,98 .

Tabel 1. Deskripsi Data

\begin{tabular}{lccccc}
\hline Variabel & N & $\begin{array}{c}\text { Mean } \\
\text { (METs) }\end{array}$ & SD & Min & Max \\
\hline Aktivitas Fisik & 65 & 34,34 & 1,22 & 31,43 & 37,97 \\
BMI & 65 & 14,72 & 1,03 & 12,45 & 17,98 \\
\hline
\end{tabular}

Berdasarkan hasil uji korelasi dan regresi diketahui tidak ada hubungan yang signifikan antara METs aktivitas fisik dengan BMI $(p>.05)$. Nilai korelasi antara METs aktivitas fisik dengan BMI adalah $r=0,039$.

Tabel 2. Hasil Uji Korelasi Antara Aktivitas Fisik dengan BMI

\section{Correlations}

\begin{tabular}{llr}
\hline & & \multicolumn{1}{c}{ BMI } \\
\hline AF & Pearson Correlation &,- 039 \\
& Sig. (2-tailed) &, 761 \\
& N & 65 \\
\hline
\end{tabular}

Tabel 3. Hasil Uji Regresi

\begin{tabular}{cccc}
\multicolumn{4}{c}{ Model Summary } \\
\hline R & R Square & $\begin{array}{c}\text { Adjusted R } \\
\text { Square }\end{array}$ & $\begin{array}{c}\text { Std. Error of } \\
\text { the Estimate }\end{array}$ \\
\hline, $039^{\mathrm{a}}$ &, 001 &,- 014 & 1,03644 \\
\hline
\end{tabular}

a. Predictors: (Constant), AP 


\section{Rachmawati Ramdani, Jajat, Nana Sutisna Risma, Adang Sudrazat}

Nilai R Square hanya 0,001 saja, yang artinya kontribusi aktivitas fisik terhadap BMI hanya $0,1 \%$. BMI dipengaruhi oleh faktor lain selain aktivitas fisik sebesar 99,9\%.

\section{Pembahasan}

Penelitian ini terfokus pada mengkaji hubungan aktivitas fisik yang diukur secara objektif dengan ActivPAL dengan BMI pada anak usia dini. Hasil penelitian disimpulkan tidak ada hubungan yang signifikan antara aktivitas fisik dengan BMI pada anak usia dini. Adapun data variabel aktivitas yang dikaji dalam penelitian ini adalah pengeluaran energi rata-rata per-hari dalam satuan METs.

Satu metabolik ekivalen (MET) didefinisikan sebagai jumlah oksigen yang dikonsumsi saat duduk diam dan sama dengan 3,5 ml O2 per kg berat badan x min. Konsep MET merupakan prosedur yang sederhana, praktis, dan mudah dipahami untuk mengekspresikan biaya energi dari aktivitas fisik sebagai kelipatan laju metabolisme istirahat (Jetté, Sidney, \& Blümchen, 1990).

Berat badan atau persentase lemak tubuh berkaitan dengan jumlah energi yang dikeluarkan, dan adanya bukti kuat tentang hubungan dosis-respons linear antara volume aktivitas fisik dan penurunan berat badan. Selain itu, peningkatan level aktivitas fisik dikaitkan dengan pencegahan kenaikan berat badan dari waktu ke waktu, tetapi sifat hubungan dosis-respons tidak jelas (Kesaniemi et al., 2001).
Tingkat obesitas yang meningkat dengan cepat mencerminkan kurangnya keseimbangan energi, ini terjadi karena sejumlah besar orang secara konsisten mengeluarkan lebih sedikit kalori daripada yang mereka konsumsi. Sayangnya, hanya sedikit data yang dapat diandalkan yang tersedia tentang kontribusi relatif terhadap epidemi obesitas ini dengan asupan energi dan pengeluaran energi, meskipun keduanya serta variasi individu adalah penting (Haskell et al., 2007).

Aktivitas fisik harus dilakukan secara rutin sejak usia dini, karena akan menentukan kondisi fisik pada saat dewasa (BarnekowBergkvist, Hedberg, Janlert, \& Jansson, 1998). Partisipasi dalam kegiatan fisik di masa dewasa harus dipelajari sejak usia muda (Aarnio, Winter, Peltonen, Kujala, \& Kaprio, 2002).

Pusat Pengendalian dan Pencegahan Penyakit (CDC) menerbitkan grafik pertumbuhan revisi untuk anak-anak dan remaja, dalam bentuk rangkaian grafik pertumbuhan. Pusat Pengendalian dan Pencegahan Penyakit (CDC) memperkenalkan penggunaan klinis dari indeks massa tubuh (BMI; dalam $\mathrm{kg} / \mathrm{m} 2$ ) dalam grafik indeks massa tubuh untuk usia untuk pria dan wanita muda berusia $2-20$ tahun. Grafik indeks massa tubuh baru ini dikembangkan dengan menggunakan data dari Survei dan Pemeriksaan Kesehatan Nasional (NHES) Siklus II dan III, data dari National Health dan Survei Pemeriksaan 


\section{Rachmawati Ramdani, Jajat, Nana Sutisna Risma, Adang Sudrazat}

Nutrisi (NHANES) I dan II, dan data untuk anak-anak usia 2 hingga 6 tahun dari NHANES III (Vital et al., 2000).

Kurva ini menjadi acuan dalam menentukan BMI pada anak usia 2 hingga 6 tahun. Namun demikian masih terdapat kontroversi ketika menentukan obesitas dengan menggunakan kriteria internasional pada populasi Asia, sehingga upaya kategorisasi BMI yang cocok untuk populasi Asia Pasifik perlu dikaji kembali (WHO/IASO/IOTF, 2000). Hubungan persentase lemak tubuh dengan BMI yang berbeda dengan populasi Eropa, sangat beresiko terhadap terkena penyakit cardiovaskuler dan diabetes jika menggunakan kriteria internasional yang merupakan titik cut-off WHO (WHO Expert Consultation, 2004).

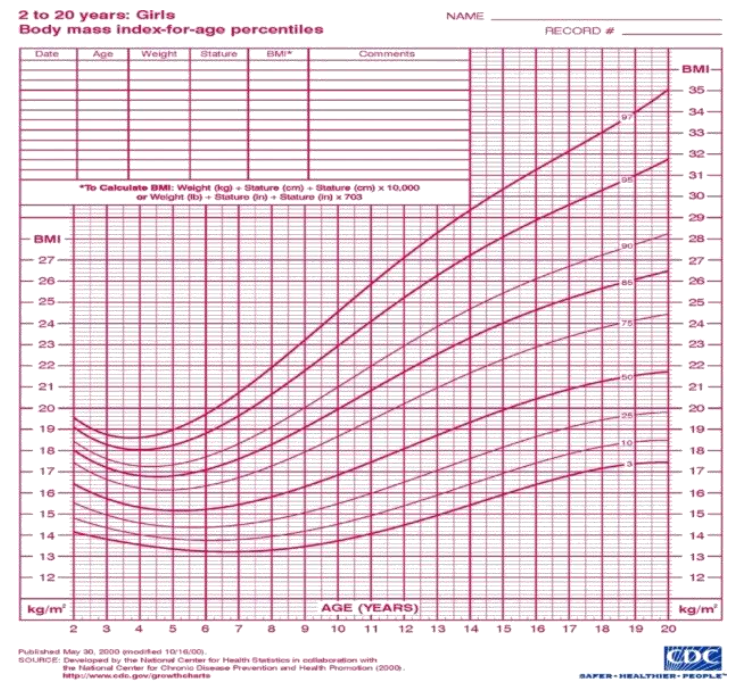

Gambar 2. Kurva Pertumbuhan BMI Lakilaki

Kegemukan merupakan hasil dari ketidakseimbangan energi di mana konsumsi kalori melebihi pengeluaran energi aktivitas fisik, komponen lunak dari pengeluaran energi (Jakicic, 2002), yang mana telah hal itu
Vol.5 No.2, 2019 (45-52)

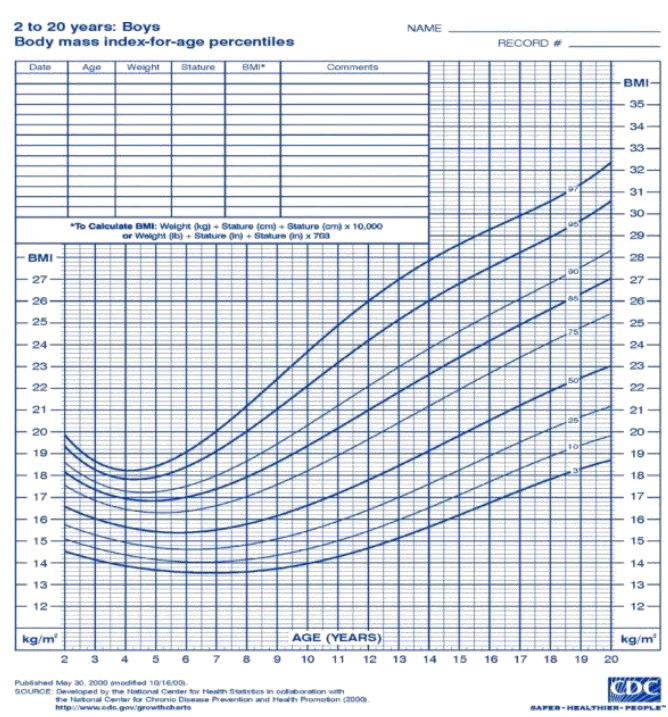

Gambar 3. Kurva Pertumbuhan BMI Perempuan

dikaitkan dengan penurunan adipositas pada anak-anak dan remaja (Abbott \& Davies, 2004). Kelebihan berat badan pada anak terkait erat dengan sejumlah besar diabetes tipe 2 dan faktor risiko penyakit kardiovaskular (Katherine M. Flega, 2001). Obesitas merupakan epidemi kesehatan yang mulai semakin dini terjadi di masa kanakkanak. Secara global, ada lebih dari 22 juta anak balita kegemukan (Deckelbaum \& Williams, 2001). Oleh karena itu, kelebihan berat badan atau obesitas di kalangan anakanak muda harus menjadi perhatian karena jika anak-anak mengalami obesitas maka risiko kesehatan lainnya akan terjadi sepanjang masa hingga anak dewasa (Nader et al., 2006).

\section{KESIMPULAN}

Hasil dari penelitian dapat disimpulkan bahwa tidak ada hubungan antara pengeluaran energi 


\section{Rachmawati Ramdani, Jajat, Nana Sutisna Risma, Adang Sudrazat}

(METs) aktivitas fisik dengan BMI pada anak usia dini.

\section{REFERENSI}

Aarnio, M., Winter, T., Peltonen, J., Kujala, U. M., \& Kaprio, J. (2002). Stability of leisure-time physical activity during adolescence - A longitudinal study among 16-, 17- and 18-year-old Finnish youth. Scandinavian Journal of Medicine and Science in Sports, 12(3), 179-185. https://doi.org/10.1034/j.16000838.2002.00250.x

Abbott, R. A., \& Davies, P. S. W. (2004). Habitual physical activity and physical activity intensity: Their relation to body composition in 5.0-10.5-y-old children. European Journal of Clinical Nutrition, $58(2)$, 285-291. https://doi.org/10.1038/sj.ejcn.160178 0

Arnardottir, N. Y., Koster, A., Domelen, D. Van, Brychta, R. J., Caserotti, P., Eiriksdottir, G., ... Sveinsson, T. (2013). Objective measurements of daily physical activity patterns and sedentary behaviour in older adults: Age, Gene/Environment SusceptibilityReykjavik Study. Age and Ageing, 42(2), 222-229.

https://doi.org/10.1093/ageing/afs16 0

Baranowski, T. (2013). Research Quarterly for Exercise and Sport $V$ alidity and Reliability of Self Report Measures of Physical Activity : An
Vol.5 No.2, 2019 (45-52)

Information-Processing Perspective Validity and Reliability of Self Report Measures of Physical Activity: (May 2015), 37-41. https://doi.org/10.1080/02701367.198 8.10609379

Barnekow-Bergkvist, M., Hedberg, G., Janlert, U., \& Jansson, E. (1998). Prediction of physical fitness and physical activity level in adulthood by physical performance and physical activity in adolescence--an 18-year follow-up study. Scand J Med Sci Sports, 8 (5 Pt 1), 299-308. https://doi.org/10.1111/j.16000838.1998.tb00486.x

Cao, C., Wang, R., Wang, J., Bunjhoo, H., Xu, Y., \& Xiong, W. (2012). Body mass index and mortality in chronic obstructive pulmonary disease: A metaanalysis. PLoS ONE, 7(8). https://doi.org/10.1371/journal.pone. 0043892

Chinapaw, M. J. M., Slootmaker, S. M., Schuit, A. J., Van Zuidam, M., \& Van Mechelen, W. (2009). Reliability and validity of the activity questionnaire for adults and adolescents (AQuAA). BMC Medical Research Methodology, 9(1), 1-8. https://doi.org/10.1186/1471-2288-958

Chodzko-Zajko, Wojtek J.,Proctor, D. N. (2009). Exercise and physical activity for older adults. Medicine and Science in Sports and Exercise, 41(7), 1510-1530. 
Rachmawati Ramdani, Jajat, Nana Sutisna

Risma, Adang Sudrazat

https://doi.org/10.1249/MSS.0b013e3

$181 \mathrm{a} 0 \mathrm{c} 95 \mathrm{c}$

Chong, W. F., Ong, K. C., Soh, C., Tan, S. P., Earnest, A., Heng, B. H., \& Cheah, J. (2004). The Body-Mass Index, Airflow Obstruction, Dyspnea, and Exercise Capacity Index in predicting hospitaliZation for Chronic Obstructive Pulmonary Disease. Chest, 126(4), 841S. https://doi.org/10.1378/chest.126.4_ meetingabstracts.841s-a

Deckelbaum, R. J., \& Williams, C. L. (2001). Childhood Obesity: The Health Issue. Obesity Research, 9(S11), 239S-243S. https://doi.org/10.1038/oby.2001.125

Esselink, A. ., Van Der Windt, D. A. W. ., Penninx, B. W. J. ., Wijnhoven, H. A. ., Twisk, J. W. ., Bouter, L. ., \& Van Eijk, J. T. . (2006). What Predicts Change in Pulmonary Function and Quality of Life in Asthma or COPD? 539, 513-519. https://doi.org/10.1080/02770900600 856954

Fletcher, G. F.,Blair, S. N.,Blumenthal, J., Caspersen, C., Chaitman, B., Epstein, S., Falls, H., Froelicher, E. S., Froelicher, V. F., \& Pina, I. L. (1992). Statement on exercise. Benefits and recommendations for physical activity programs for all Americans. A statement for health professionals by the Committee on Exercise and Cardiac Rehabilitation of the Council on Clinical Cardiology, American Heart associ. Circulation, 86(1),
Vol.5 No.2, 2019 (45-52)

340-344.

https://doi.org/10.1161/01.CIR.86.1.3

40

Ford, E. S. (1999). Body mass index, diabetes, and C-reactive protein among U.S. Adults. Diabetes Care, 22(12), 1971-1977. https://doi.org/10.2337/diacare.22.12. 1971

Gray, C. L., Messer, L. C., Rappazzo, K. M., Jagai, J. S., Grabich, S. C., \& Lobdell, D. T. (2018). The association between physical inactivity and obesity is modified by five domains of environmental quality in u.S. Adults: A cross-sectional study. PLOS ONE, 13(8). https://doi.org/10.1371/journal.pone. 0203301

Haskell, W. L., Lee, I. M., Pate, R. R., Powell, K. E., Blair, S. N., Franklin, B. A., ... Bauman, A. (2007). Physical activity and public health: Updated recommendation for adults from the American College of Sports Medicine and the American Heart Association. Medicine and Science in Sports and Exercise, 39(8), 1423-1434. https://doi.org/10.1249/mss.0b013e3 180616b27

Jakicic, J. M. (2002). The Role of Physical Activity in Prevention and Treatment of Body Weight Gain in Adults1,2. (1988), 3825-3826. https://doi.org/10.1111/j.10958649.2006.01007.x

Jetté, M., Sidney, K., \& Blümchen, G. (1990). 
Metabolic equivalents (METS) in exercise testing, exercise prescription, and evaluation of functional capacity. Clinical Cardiology, 13(8), 555-565. https://doi.org/10.1002/clc.49601308 09

Katherine M. Flega. (2001). Diabetes, Impaired Fasting Glucose, and Elevated $\mathrm{Hb} A 1 \mathrm{c}$ in $\mathrm{U}$ . S . Adolescents: The. (February), 24-27.

Katsura, H., Yamada, K., \& Kida, K. (2005). Both generic and disease specific bealth-related quality of life are deteriorated in patients with underweight COPD \$. 624-630. https://doi.org/10.1016/j.rmed.2004.0 9.017

Kesaniemi, Y. A., Danforth E., J., Jensen, M. D., Kopelman, P. G., Lefebvre, P., \& Reeder, B. A. (2001). Dose-response issues concerning physical activity and health: An evidence-based symposium. Medicine and Science in Sports and Exercise, $33(6 \quad$ SUPPL.), 351-358. https://doi.org/10.1097/00005768200106001-00003

Mokdad, A. H., Ford, E. S., Bowman, B. A., Dietz, W. H., Vinicor, F., Bales, V. S., \& Marks, J. S. (2015). Prevalence of Obesity, Diabetes, and Obesity-Related Health Risk. Factors, 2001. 289(1), 2001-2004.

Nader, P. R., O’Brien, M., Houts, R., Bradley, R., Belsky, J., Crosnoe, R., ... Susman, E. J. (2006). Identifying Risk for Obesity in Early Childhood. Pediatrics, 118(3), e594-e601. https://doi.org/10.1542/peds.2005-

2801

Noûs, S., Division, A. P. A. C., \& Mar, M. (2018). Symposium Papers, Comments and an Abstract: The Sociology of Knowledge About Child Abuse Author (s ): Ian Hacking Published by: Wiley Stable URL: bttp:/ / www.jstor.org/stable/ 2215550

REFERENCES Linked references are available on JSTOR for this article (Vol. 22, pp. 53-63). Vol. 22, pp. 53-63.

Shephard, R. J. (2003). Limits to the measurement of habitual physical activity by questionnaires * Commentary. British Journal of Sports Medicine, 37(>3), 197-206. https://doi.org/10.1136/bjsm.37.3.197 Taylor, Rod S. Brown. (2004). Exercise-based rehabilitation for patients with coronary heart disease: Systematic review and meta-analysis of randomized controlled trials. American Journal of Medicine, 116(10), 682-692. https://doi.org/10.1016/j.amjmed.200 4.01 .009

Tudor-Locke, C. E., \& Myers, A. M. (2001). Challenges and opportunities for measuring physical activity in sedentary adults. Sports Medicine, 31(2), 91-100. https://doi.org/10.2165/00007256200131020-00002

Vital, F., Kuczmarski, R. J., Ogden, C. L., Grummer-strawn, L. M., Activity, P., Flegal, K. M., ... Johnson, C. L. (2000). CDC Growth Charts: United States. Advance Data, Jun 8(314), 1-27. 